\title{
Does human capital play an important role in farm size growth? The case of Slovenia
}

\author{
Štefan Bojnec*, ImRe Fertő**
}

DOI: $10.30682 / \mathrm{nm} 2101 \mathrm{~d}$

JEL codes: C21, C23, I25, Q12, Q18

\begin{abstract}
The paper investigates the drivers of farm size and farm size growth in Slovenia during the period 20072017 using a farm-level Farm Accountancy Data Network dataset within a quantile regression framework. Farm size growth is measured by growth in utilized agricultural area per farm. The findings suggest that growth in farm land size is driven by initial farm land size and policy subsidy support. Contrary to expectations, human capital does not play an important role in either farm land size or farm land size growth according to quantile regressions. These findings from inter-quantile comparative analysis are important for farm-related structural and rural development policy.
\end{abstract}

Keywords: Farm growth, Human capital, Subsidies, Slovenian Farm Accountancy Data Network.

\section{Introduction}

It is well known from the literature that the number of farms in developed countries has declined, and also that average farm size has increased (Eastwood et al., 2010; Lowder et al., 2016). The relationship between farm size and farm size growth indicates structural changes in farms with implications for farm policy and managerial farm practices and competitiveness. The claim that the relationship between farm/firm size growth and farm/firm size is independent is known in the literature as Gibrat's (1931) Law (Distante et al., 2018). The motivation behind this paper is a desire to move a step beyond testing the validity of Gibrat's Law and investigate the drivers of Slovenian farm size growth to bet- ter understand the mechanisms of farm structural change, and the key drivers that influence the observed trends in farm size growth.

In empirical studies, several factors have been identified as influencing farm structural change, including relative prices, technological change, size economies, farm debt, sunk costs, policy variables, demographic variables, and indicators related to off-farm employment and regionally specific patterns and spatial dependencies (Goddard et al., 2002; 2006; Huettel and Jongeneel, 2011). Akimowicz et al. (2013) developed and tested a model of drivers of farm size growth in Southwestern France. Barbosa (2020) investigated Portuguese farming firms' growth, focusing on human capital and managerial capa-

\footnotetext{
* University of Primorska, Faculty of Management, Koper - Capodistria, Slovenia.

** Institute of Economics, Centre for Economic and Regional Studies, Lorand Eotvos Research Network, Budapest, Hungary; Hungarian University of Agricultural and Life Sciences, Kaposvár Campus, Faculty of Business Administration, Kaposvár, Hungary.

Corresponding author: stefan.bojnec@fm-kp.si
} 
bilities, while Adinolfi et al. (2020) investigated gender differences in farm entrepreneurship and farming performance in Italy. Although there is literature about structural change in agriculture, our understanding of different patterns of structural change is limited.

The farm size required (in terms of economies of size in the short term, and scale and scope economies in the long term) to reach (steady) equilibrium can be determined by various factors (Jones and Kalmi, 2012; Akimowicz et al., 2013; Adamopoulos and Restuccia, 2014; Gollin, 2019). Our aim is to specify and establish a robust relationship between farm size growth and its driving forces in terms of farm-specific utilized agricultural area (UAA) and the share of rented land, farmer/manager personal- or human-capital-related factors (age, education/training, and gender), policy factors (subsidies), and territorial or rural variables. It is known from the literature that farms are heterogeneous and that the dynamics of structural change differ between countries and farm-size categories over time (Upton and Haworth, 1987; Johnson and Ruttan, 1994; Weersink, 2018; Colombo et al., 2018).

In comparison to previous studies, this paper adds to the exiting literature by specifying the drivers of farm size growth while controlling for potential farm-specific effects that could influence the results. As novelty is the use of quantile regression techniques and the implications of this methodological approach with additional information that can provide in comparison to more conventional regression methods. The shape of farm size distribution across quantiles can provide a better understanding of the structure of these effects, which can differ across quantiles. Finally, in addition to the contribution the research makes to the literature, the importance of this paper for farm structural policy is related to its use of inter-quantile comparative analyses. It is thus also of relevance to rural development policies and farm managerial and entrepreneurial practices that involve responding to a changing institutional and policy-enabling environment.

The rest of the paper is organized as follows. First, we briefly describe pre-existing literature about firm/farm size growth. Then, we present the methodology, data, and the empirical results of quantile regressions. This is followed by a discussion and description of the implications of the results. The final section derives the main conclusions.

\section{Pre-existing literature}

In the literature there is no a single measure of farm size (Lund, 1983; Lund and Price, 1998; Alvarez and Arias, 2004) and different measures have been used to capture this factor, such as the physical magnitude of inputs (e.g. total UAA per farm, or total head of livestock per farm), and the economic size of outputs. Akimowicz et al. (2013) argue that the choice of UAA per farm may be a more relevant measure of farm size than one related to economic farm size due to the variability of farm production choices and commodity prices over time. Similarly, in our study, UAA per farm is used as a measure of farm size and farm size growth. Farm size growth measured as an increase in UAA per farm may be limited by the quantity of UAA that is available and the number of farms. While a part of UAA can be dedicated to non-agricultural uses and vice versa, a decrease in the number of farms can determine the increase in the remaining average farm size, which can thus be differently distributed over time.

One strand of literature focuses on the drivers of farm size growth using Gibrat's Law of proportionate growth, which specifies that farm size growth is unrelated to initial farm size. The idea that no equilibrium farm size exists may suggest that farm size growth is a random phenomenon. Empirical research has yielded rather contradictory results about the relationship between farm size and the growth of farm size by country and over time. Some studies (Weiss, 1998; Rizov and Mathijs, 2003; Bakucs and Fertő, 2009) have rejected the validity of Gibrat's Law for farm size growth, finding that small farms tend to grow faster than large ones. Other studies (Kostov et $a l ., 2005$ ) found no evidence to reject the validity of Gibrat's Law. Bakucs et al. (2013) investigated the relationship between farm size and farm size growth in field crop and dairy farms in France, Hungary, and Slovenia using quantile regression. The results for Hungary are consistent with previous studies that suggested that Gi- 
brat's Law should be rejected because smaller farms grow faster than their larger counterparts. Similarly, the validity of Gibrat's Law can be rejected for French and Slovenian dairy farms, but not for Slovenian crops farms, because the rate of growth of crop farms in terms of land is independent of their size. Bojnec and Fertö (2020a) investigated the validity of Gibrat's Law for the growth of a sample of Slovenian farms in the period 2007-2015 using a cross-sectional dependence test and four different groups of panel unit root tests. The results confirmed the validity of Gibrat's Law independent of measures of farm size (inputs in the form of land and labour per farm, and outputs as economic size per farm) and type of panel unit root test. All farm sizes witnessed an increase in average farm size. Bojnec and Fertö (2020b) compared the growth of Hungarian and Slovenian samples of farms using quantile regression for the period 20072015. Results suggested rejecting the validity of Gibrat's Law for Hungarian farms, and, to a lesser extent, for Slovenian farms when the growth of farms was measured by growth of output per farm (where smaller farms grew faster than the largest farms), but not in relation to an increase in farm inputs (i.e. land and labour per farm). Smaller, mostly individual Hungarian farms grew faster than larger, mostly corporate farms.

Akimowicz et al. (2013) investigated drivers of farm size growth in Southwestern France. The former examined the factors that can explain farm size growth in developed countries, among them farm structural change (which can be expressed by the diversification of farm activities, farm mechanization, and specialization), the search for an equilibrium farm size or economies of scale or economies of scope, farmer- and human-capital-related factors, other classical factors, and territorial spatial factors that depend on farm location. Farm mechanization and specialization may be important drivers of farm structural change and farm size growth, generating economies of scale (Chavas, 2001). Some previous studies have highlighted that farm size can be determined by human capital and managerial capabilities (Barbosa, 2020) such as farmer age, the experience of the former in the agricultural sector, their level of schooling, and the management techniques that are applied (Sumner and Leiby, 1982).

Akimowicz et al. (2013) found that farm size growth was significantly driven by farm structural characteristics, the farmer's age, the existence of a successor, and spatial rural-urban influences, but not human capital variables. Similarly to the area of interest of Akimowicz et al. (2013), our paper focuses on drivers of farm size growth and the intensity of farm size growth by different quantiles. We investigate the drivers of farm land size and farm land size growth in Slovenian agriculture with a focus on initial farm size in terms of UAA per farm and the share of rented land, farmer/manager personal- or human-capital-related factors (age, education/training, and gender), farm subsidies, and farm location in rural areas. Our main hypothesis is that farmer/manager personal- or human-capital-related variables are positively related to land farm size distribution and land farm size growth (Sumner and Leiby, 1987; Barbosa, 2020). However, Akimowicz et al. (2013) and Barbosa (2020) have reported mixed findings in relation to different farmer/manager personal and human capital variables.

\section{Methodology}

Different econometric approaches have been developed in the literature to test the validity of Gibrat's Law (the relationship between farm size and farm size growth). Studies of drivers of farm size growth, in addition to initial farm size, include various control variables related to farm-specific variables on the input and output side, as well as policy and territorial factors (Akimowicz et al., 2013).

The econometric specification of the regression used specifically for testing the validity of Gibrat's Law with the definition of model variables is the following equation (1), which represents the stochastic process underlying Gibrat's (1931) Law:

$$
\frac{S_{i, t}}{S_{i, t-1}}=\alpha S_{i, t-1}^{\beta_{1}-1} \varepsilon_{i, t}
$$

where $S_{i, t}$ and $S_{i, t-1}$ are the size of the $i^{\text {th }}$ farm in the period $t$ and in the previous period $t-1$, respectively. $\varepsilon i, t$ is the disturbance in period $t$, 
independent of $S_{i, t-1 . \alpha}$ is the common growth rate of all farms, whilst $\beta 1$ measures the effect of initial size upon the given farm's growth rate. If $\beta 1=1$, then farm size growth rate and initial farm size are independently distributed, indicating that Gibrat's Law holds. If the coefficient is less than one, it follows that small farms tend to grow faster than large farms, while the opposite is the case if $\beta 1$ is greater than unity.

Rewriting equation (1) in the form represented by equation (2) allows for the testing of the significance of the coefficient $\beta 1$ :

$$
\log S_{i, t}=\beta_{0}+\beta_{1} \log S_{i, t-1}+\mu_{i . t}
$$

where $\beta 0=\log \alpha$ and $\mu i, t=\log \varepsilon i, t$, where $\log$ is the natural logarithm. Following Ward and McKillop (2005), if $\beta 1=1$ (i.e. Gibrat's Law holds), then positive (negative) values of $\beta 0$ indicate growth (decrease) in average farm size. If, however, $\beta 1<1$, then smaller farms tend to grow faster than larger ones.

The growth model is modified by redefining the dependent variable as the first difference of the logarithm of farm land in equation (2):

$$
\log S_{i t}-\log S_{i t-n}=\beta_{0}+\beta_{1} S_{i t-n}+X_{i t-1} \gamma+\mu_{i t}
$$

where $\mathrm{X}_{\mathrm{it}} \mathrm{1}$ represents a group of additional covariates.

In the OLS regression estimation, error terms are assumed to follow the same distribution irrespective of the value of the explanatory variables. Since we can only analyse surviving farms, estimations are conditional on survival (conditional objects, see Lotti et al., 2003).

Empirical studies on land-use and land-cover change with impact on landscape have applied different methodological approaches in literature to study and predict farm size and farm size growth, its drivers and causes from smart farming towards agriculture 5.0, including econometric, agent-based models (Parker et al., 2002; Beckers et al., 2018), stellate model, and machine learning technics (Pantazi et al., 2016; Wolfert et al., 2017; Rudd et al., 2017; Saiz-Rubio and Rovira-Más, 2020; Mekonnen et al., 2020). Among methodological approach- es particularly related to spatially land-use and land-cover change models we have selected the econometric approach with applied the quantile regression models to study drivers of farm size distribution across quantiles.

Therefore, in this paper we use the quantile regression estimation technique. Following Lotti et al. (2003), the $\theta^{\text {th }}$ sample quantile, where $0<\theta$ $<1$, can be defined as:

$$
\min _{b \in R}\left[\sum_{i \in\left\{i: y_{i} \geq b\right\}} \theta\left|y_{i}-b\right|+\sum_{i \in\left\{i: y_{i}<b\right\}}(1-\theta)\left|y_{i}-b\right|\right]
$$

where yi and b are estimated for any quantile within the range of zero and one.

For a linear model such as $y_{i}=\beta^{\prime} x_{i}+\varepsilon_{i}$, the $\theta^{\text {th }}$ regression quantile is the solution of the minimization problem, similar to equation (4):

$$
\min _{b \in R^{k}}\left[\sum_{i \in\left\{i: y_{i} \geq x_{i} b\right\}} \theta\left|y_{i}-x_{i} b\right|+\sum_{i \in\left\{i: y_{i}<x_{i} b\right\}}(1-\theta)\left|y_{i}-x_{i} b\right|\right]
$$

Solving equation (5) for $b$ provides a robust estimate of $\beta$.

To keep the same farms in the balanced panel dataset during the analysed period, the sample size reduces considerably. Nikitina et al. (2019) suggests to apply bootstrapped quantile regression approach for small sample size. We have addressed small sample size issue applying bootstrapped quantile regression models with bootstrapped standard errors using 1000 replications.

\section{Data}

We employ farm-level data from the Slovenian Farm Accountancy Data Network (FADN) sample of farms to analyse drivers of farm land size and farm land size growth during the period 2007-2017. We use farmer/manager personal- or human-capital-related variables: age, education/ training (defined as 1: primary school, 2: high school, 3: university), and a gender dummy which is equal to one if farmer is female, and zero for male. Rural is a dummy variable which takes a value of one if the farm is located in a rural area in terms of the European Commission classification, and is zero otherwise. As a policy var- 
iable, we use total subsidies in euros (SE605). The Statistical Office of Slovenia (SORS) price indices are used as deflators of nominal values over time with a 2010 base year. We use balanced panel data.

\section{Results}

We first present descriptive statistics and then econometric models.

\subsection{Descriptive statistics}

Table 1 illustrates the averages of farm size and explanatory variables in the reference year 2007 and the final analysed year 2017. UAA farm size is used as the farm size variable. The average size of farmland in UAA was 16.4 ha per farm in 2007, while the largest farm in the sample was 110.6 ha. Average farm size increased by 0.9 hectares between 2007 and 2017. Farms in Slovenia are still largely cultivating their own land, although the share of rented land has stabilised. In 2007 and 2017, on average 30\% and $29 \%$, respectively, of land was rented (ranging from farmers cultivating only their own land - i.e. no rented land -, to farms operating on completely rented land, the latter situation more often being the case with the few privatized commercial farms which typically rent land from the state fund for agricultural land and forests). Subsidies are an important source of farm income. For the analysed sample of farms, they increased at constant prices of 2010 from 9,667 euro per farm in 2007 to 11,187 euro per farm in 2017. Most farm managers and farm owners have some kind of agricultural education, which has increased during the analysed period. Their average age in the reference year 2007 was 42.8 years and in the final year 2017 was 52.2 years, while during the period of analysis the average age was 48.3 years, and $81 \%$ farm managers and farm owners were male.

To present density estimation on grouped data graphically in the case of mean values of farm size expressed in UAA in ha per farm, we use a comparison of kernel density distribution function with parametric estimation of the Lorenz curve which is also applied to grouped data.

While there were no radical changes in farm size land distribution between 2007 and 2017, the kernel distribution function for land (UAA in ha per farm) in Figure 1 confirms a slight shift in average farm size land concentration towards rights suggesting a slightly larger average farm land size.

Table 1 - Descriptive statistics of variables (reference year 2007 and final year 2017).

\begin{tabular}{|l|c|r|r|r|r|}
\hline Variables & $\begin{array}{c}\text { Number of } \\
\text { observations }\end{array}$ & \multicolumn{1}{|c|}{ Mean } & \multicolumn{1}{c|}{ Std. Dev. } & \multicolumn{1}{c|}{ Min } & \multicolumn{1}{c|}{ Max } \\
\hline Land (in UAA in ha) 2007 & 113 & 16.4 & 13.4 & 3.0 & 110.6 \\
\hline Land (in UAA in ha) 2017 & 113 & 17.3 & 13.7 & 2.7 & 100.2 \\
\hline Age (in years) 2007 & 113 & 42.8 & 13.3 & 14.0 & 73.0 \\
\hline Age (in years) 2017 & 113 & 52.2 & 13.5 & 23.0 & 83.0 \\
\hline Training dummy 2007 & 113 & 1.44 & 0.63 & 1.00 & 3.00 \\
\hline Training dummy 2017 & 113 & 1.63 & 0.68 & 1.00 & 3.00 \\
\hline Gender dummy 2007 & 113 & 0.19 & 0.39 & 0.00 & 1.00 \\
\hline Gender dummy 2017 & 113 & 0.19 & 0.39 & 0.00 & 1.00 \\
\hline Rented land (in \%) 2007 & 113 & 30 & 28.1 & 0.00 & 100 \\
\hline Rented land (in \%) 2017 & 113 & 29 & 27.4 & 0.00 & 100 \\
\hline Total subsidy (in euro) 2007 & 113 & 9667.1 & 8921.1 & 0.0 & 66601.0 \\
\hline Total subsidy (in euro) 2017 & 113 & 11186.9 & 10934.6 & 1175.0 & 66013.6 \\
\hline
\end{tabular}

Source: Authors' estimations based on FADN data. 
Figure 1 - Kernel distribution function for land (UAA in ha per farm).

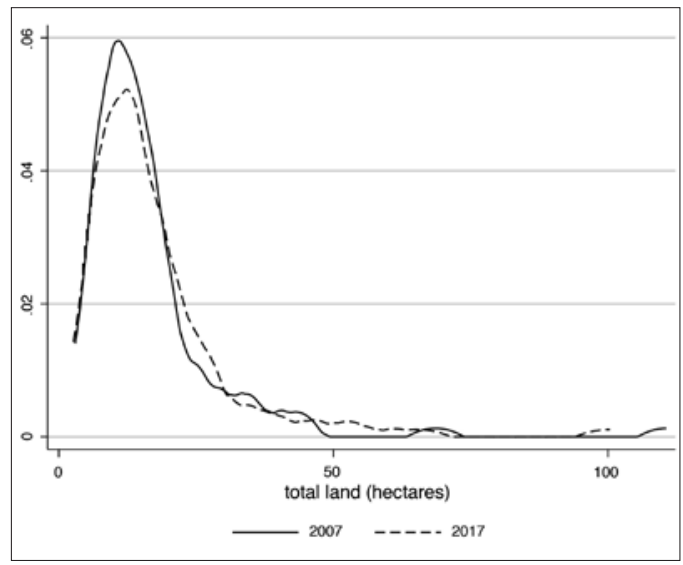

Source: Authors' estimations based on FADN data.

A slight increase in average land farm size is seen from the Lorenz curves for the distribution of land in UAA in ha per farm (Figure 2). Finally, Lorenz curves of farm size land distribution close to the $45^{\circ}$ line, which means a linear distribution, suggest a more equal than unequal land farm size distribution in the Slovenian farming structure.

\subsection{Econometric models}

We test two econometric models that were designed to explain two aspects of farm size growth. First, the logarithm of farm size observed in 2007 expressed in terms of UAA per farm, specified as $\log$ (land in UAA) per farm in 2007. Second, the logarithm of the intensity of growth between 2007 and 2017, the period for when growth is, as expressed in equation (3). The aim of using the two models was to compare the effect of the explanatory variables on indicators of farm size and their evolution. The first regression reveals the impacts of various factors on initial farm size. The second regression focuses on the effects of the same explanatory variables on the intensity of farm size growth. Notice that the explanatory variables we employed concerned the year 2007, and these are the initial characteristics likely to explain the variation in farm size, and, more particularly, the growth in farm size in terms of both variables observed in 2017.
Figure 2 - Lorenz curves for land distribution (UAA in ha per farm).

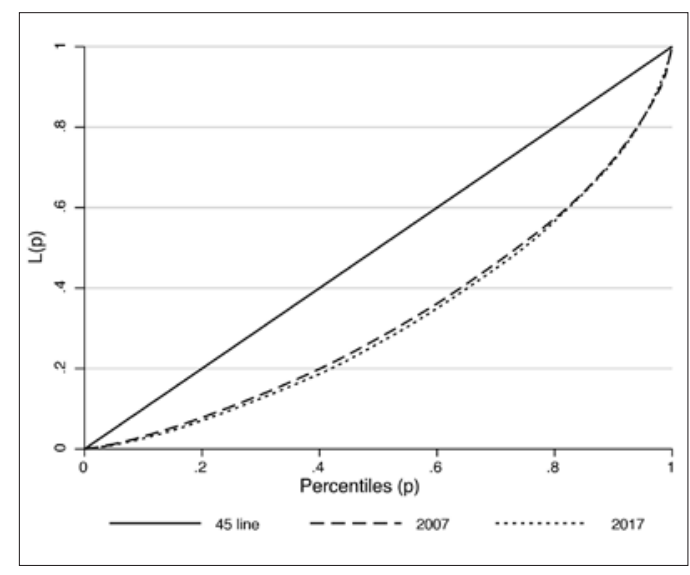

Source: Authors'estimations based on FADN data.

Table 2 presents quantile regressions of $\log$ (land in UAA) per farm in 2007. The results of these quantile regressions are mixed and suggest that agricultural education/training has a negative impact for q10, but is insignificant for the remaining quantiles. The cultivation and operation of the smallest farms requires less knowledge and experience. Farm growth is positively linked to the proportion of rented land and log (subsidy) received by all quantiles. As subsidy payments are input-based, there was a positive link between subsidies and the growth of farm size in UAA from 2007 onwards. Farm size growth is negatively linked to the variable female for q90, while for other quantiles the role of gender in farm size growth is insignificant. Also insignificant is the role of the age and rural dummies on farm size growth by all quantiles. We also estimated our models with squared age variable, but the coefficients were insignificant for both level and squared terms in all quantiles. Therefore, except for training and gender, no other considerable inter-quantile differences can explain the structural changes in the farming sector and/or potential changes in (nor specificity of) technology related to UAA per farm size growth since 2007. A significant positive influence for farm size growth of log (land in UAA) per farm in 2007 is mainly caused by the share of rented land and subsidies, with some differences in magnitude across quantiles. 
Table 2 - Quantile regression for farm land size: $\log$ (land in UAA) per farm in 2007.

\begin{tabular}{|l|c|c|c|c|c|}
\hline & $q 10$ & $q 25$ & $q 50$ & $q 75$ & $q 90$ \\
\hline Age & -0.001 & 0.000 & 0.000 & 0.001 & 0.001 \\
\hline Training & $-0.095^{* * *}$ & -0.030 & 0.039 & 0.023 & 0.030 \\
\hline Gender & -0.042 & -0.035 & -0.030 & -0.079 & $-0.329 * * *$ \\
\hline Rented land & $0.463 * * *$ & $0.448^{* * *}$ & $0.334 * *$ & $0.659 * * *$ & $0.456^{*}$ \\
\hline $\log$ (subsidy) & $0.777^{* * *}$ & $0.738^{* * * *}$ & $0.678^{* * *}$ & $0.589 * * *$ & $0.518^{* * *}$ \\
\hline Rural & 0.018 & 0.036 & -0.029 & 0.009 & -0.205 \\
\hline Constant & $-4.605 * * *$ & $-4.351 * * *$ & $-3.637 * * *$ & $-2.773 * * *$ & -1.633 \\
\hline Number of observations & 109 & 109 & 109 & 109 & 109 \\
\hline Pseudo $\mathrm{R}^{2}$ & 0.6066 & 0.5408 & 0.5069 & 0.4917 & 0.5019 \\
\hline
\end{tabular}

Note: $* * * p<0.01, * * p<0.05, * p<0.1$.

Table 3 presents the results of quantile regression for land size changes specified as log (land in UAA) per farm between 2007 and 2017. Farm size growth between 2007 and 2017 is negatively linked with initial land farm size, which is, except for q10, statistically significant by quantile. In contrast, farm land size growth is positively associated with log (subsidy) payments, which are, except for q10, statistically significant by quantile. Female farm owners and managers negatively influence farm land size growth for q50 and q75, and are otherwise insignificant for other quantiles. The non-linear impact (by quantile) on farm land size growth is related to the proportion of rented land, which is significantly positive for q50 and q75. In addition, except for q10, log (subsidy) by quantile is positive and significant. The impact of age is, except for q25, insignificant (negatively influencing farm land size growth in q25). The impact of education/training and rural is insignificant.

Table 3 - Quantile regression for farm land size changes: log (land in UAA) per farm between 2017 and 2007.

\begin{tabular}{|l|c|c|c|c|l|}
\hline & $q 10$ & $q 25$ & $q 50$ & $q 75$ & \multicolumn{1}{|c|}{$q 90$} \\
\hline $\log$ (land) & -0.370 & $-0.269 * * *$ & $-0.294^{* * *}$ & $-0.297 * *$ & $-0.232^{*}$ \\
\hline Age & -0.005 & $-0.003^{*}$ & -0.002 & -0.003 & 0.002 \\
\hline Training & -0.025 & 0.016 & 0.014 & 0.004 & -0.071 \\
\hline Gender & 0.022 & -0.011 & $-0.080^{*}$ & $-0.096^{*}$ & -0.140 \\
\hline Rented land & 0.079 & 0.060 & $0.209^{* *}$ & $0.216^{*}$ & 0.147 \\
\hline $\log$ (subsidy) & 0.236 & $0.223^{* * *}$ & $0.210^{* * *}$ & $0.241^{* * *}$ & $0.265^{* * *}$ \\
\hline Rural & 0.009 & 0.032 & -0.005 & -0.049 & 0.046 \\
\hline Constant & -1.131 & $-1.326^{* * *}$ & $-1.063 * * *$ & $-1.151^{* *}$ & $-1.463 * *$ \\
\hline N & 109 & 109 & 109 & 109 & 109 \\
\hline Pseudo $\mathrm{R}^{2}$ & 0.2088 & 0.1042 & 0.0627 & 0.1005 & 0.1117 \\
\hline
\end{tabular}

Note: $* * * p<0.01, * * p<0.05, * p<0.1$. 


\section{Discussion and implications}

Farm size distribution, farm structural changes, and drivers of farm size growth are some of the most often studied research issues in agricultural economics (Sumner, 2014). They are also common subjects of agricultural and rural development policy objectives related to diversified spatial farming structures in developed and developing countries and are considered important variables in relation to competitiveness, and agricultural and farm sustainable development (Key and Roberts, 2007; Piet et al., 2012; Bartolini and Viaggi, 2013). According to the 2010 General Agricultural Census (Eurostat, 2020a) and the 2016 Farm Structure Survey (Eurostat, 2020b), farm fragmentation of the smallest farms, farm concentration of the largest farms, and farm size growth vary considerably across EU-28 member states. The heterogeneity in farm size distribution has also been confirmed by the typology and distribution of small farms in Europe (European Commission, 2013; D'Amico et al., 2013; Guiomar et al., 2018).

Our analysis focuses specifically on a sample of Slovenian FADN farms. Slovenia can be classified as one of a number of EU-28 member states that have on average smaller but growing average farm size (Bojnec and Fertö, 2020a; 2020b). Similarly to some other countries, farm exit occurs particularly among farms of medium size in Slovenia (Bojnec and Latruffe, 2013).

The present study has confirmed five main findings that have farm managerial and policy implications. First, there is a negative relationship between initial farm land size and farm land size growth. This suggests that large farms are growing less than small ones, confirming earlier results for Slovenian agriculture (Bakucs et al., 2013). The policy insight is that different initial farm sizes are an important variable in farm size growth and diversification (Melhim et al., 2009). In the short term, this may be connected to an increase in economies of size, while in the long term it may be associated with a combination of both scope economies for smaller and mixed farms, and scale economies for larger and more specialized farms (in terms of land use). Among the latter farms, this may involve larger special- ized crops farms, and more extensive livestock and dairy production on grassland (i.e., widespread pastures and meadows, particularly in less favoured hilly and mountain areas).

Second, in contrast to theoretical expectations, farmer-specific personal characteristics and human-capital-related variables do not play an important role in farm land size and farm land size growth (Sumner and Leiby, 1982). This a striking finding, although the situation regarding farmer/manager education/training for Slovenia is similar, for example, to that identified by Akimowicz et al. (2013) for Southwestern France. However, in Slovenia, the age of farmers was found to be insignificant across quantiles, while greater female participation reduces farm land size and farm land size growth in upper quantiles. Therefore, farmer/manager-specific personal characteristics and human-capital-related variables were largely found to be an insignificant driver of farm land size and farm land size growth for the Slovenian sample of FADN farms for most quantiles.

Third, a greater share of rented land is associated with greater farm land size, and, to a lesser extent, contributes to farm land size growth for upper quantiles, except for the largest farm land size, which might indicate limitations in terms of further farm land size growth. These findings suggest that the renting of land and land-leasing arrangements have become an important driver in the restructuring of the Slovenian farming structure towards farm size growth. While traditional family farms mostly operated on their own land (traditional or peasant farming), this has changed towards more entrepreneurial operations that involve the renting of land.

Fourth, subsidies positively influence both farm land size and farm land size growth. Accordingly, generous Common Agricultural Policy (CAP) subsidies are found to be a crucial driver of farm land size for all quantiles, and farm land size growth for the Slovenian sample of FADN farms by quantile, except for the lowest q10. This finding may be important from a farm managerial perspective, as CAP subsidies can be an important driver of farm profitability and a relatively stable source of farm revenue, but are also policy - and thus politically depend- 
ent. CAP subsidies in Slovenian agriculture have been found not only to be important, but also one of the most stable sources of farm income (Bojnec and Fertő, 2018; 2019a; 2019b). However, offering generous CAP subsidies has important policy implications. Any changes or reductions in CAP subsidies could have a diminishing effect on farm land size, with the potential abandonment of operations, particularly in depopulated, remote, and less favoured areas, and generally on farm land size growth in Slovenia. However, Unay-Gailhard and Bojnec (2019) find that agri-environmental policy measures supported with subsidies can create green jobs on Slovenian farms, particularly in relation to family labour on large dairy family farms and hired labour in large field crop farms. On the other hand, Baráth et al. (2020) did not find a significant effect for three different types of subsidies - investment-, less-favoured-area-, and agri-environmental subsidies - on total factor productivity and its three different components (technical efficiency, scale efficiency, and technological change) in Slovenian agriculture during the period 2006-2013. Therefore, as public budgets and subsidies are limited and politically dependent on CAP changes, there is a need to improve the targeting, management, and monitoring of efficiency in subsidy implementation: a crucial implication for policy, managerial, and farm entrepreneurial practices.

Shifting from a government-supported to a more entrepreneurial farming structure (probably involving a decrease in subsidies) requires improvements of the institutional and organizational structure of farming and in agri-food value chains such as promoting the role of farmer-based organizations for value chain integration (Francesconi and Wouterse, 2015) and networking for small farms as a factor for entrepreneurship (Aubert and Perrier-Cornet, 2009; De Hoyos-Ruperto et al., 2013; Ciliberti et al., 2020). A greater role can play by changes in farm income diversification and farm income sources on entrepreneurially oriented farms and small- and medium-sized enterprises (Gričar et al., 2019). More entrepreneurial farms and farm size growth can be combined through new technological innovation, including open innovation from outside farms and the greater transfer of knowledge into farming and agri-food value chain practices. Different types of innovation approaches may include product innovation involving the implementation of new or significantly improved products or services (OECD, 2009), process innovation with new or improved farm production technologies or delivery methods for increasing added value (such as in short-supply chains in local agri-food markets and in online agri-food shopping), marketing innovation through different marketing channels to obtain higher prices, and organisational innovation that leverages economies of scale for relatively small- and medium-size farms, such as setting-up producer associations and making improvements in service cooperatives (e.g. in their organisation and communication) and contract farming that can improve efficiency and add value (OECD, 2015; Benke and Tomkins, 2017; Mishra et al., 2018).

Finally, farm growth may be related to some other factors, among them farm investment, where an important role may be played by financial constraints, farm efficiency, and financial status or farm indebtedness (Bojnec and Fertő, 2016). As argued by Fagiolo and Luzzi (2006) for the Italian manufacturing industry and Donati (2016) for the manufacturing and service sectors in Italy, firm size and firm size growth can be explained by liquidity constraints. Farm growth can also be heterogeneous in relation to types of farming and natural factor endowments and in terms of locational factors and regional specificities. Baráth et al. (2018) investigated and compared the effect of heterogeneity on production technology and technical efficiency for a sample of less- favoured-area and non less-favoured-area Slovenian FADN farms. The striking finding was that farms in less-favoured-areas are not more inefficient, but rather use different, production-environment-specific technologies.

\section{Conclusions}

This paper deals with the drivers of farm land size and farm land size growth in Slovenia. It adds to the existing literature evidence on the drivers of farm size and farm size growth with important farm managerial and policy impli- 
cations. The analysis does control for possible farm-specific effect influencing the results. The main findings lead to the conclusion that initial farm size and CAP subsidies are the main drivers of farm land size and farm land size growth in Slovenia. However, the results suggest some diversity across different quantiles.

The main novelty lies in the application of advanced quantile regression econometric methodology to FADN farm level data using more explanatory variables. The paper starts with the hypothesis that farmer/manager personal or human capital variables can play a positive role in land farm size and land farm size growth. However, the results suggest that farmer/manager-specific personal characteristics and human-capital-related variables were largely found to be insignificant according to quantiles for farm land size and farm land size growth in Slovenia. The negative relationship between initial farmland size and farm land size growth suggests that large farms are growing less than small ones. In terms of farm land size and farm land size growth, the impact of generous CAP subsidies exceeded that of all other drivers. Renting of land and land leasing arrangements have become an important driver of restructuring of the Slovenian farming structures.

The findings from this study can be applied in the more general setting of farm size growth when relatively small- to medium-sized farms dominate farming structures. This is the situation in the countries neighbouring Slovenia on the territory of the former Yugoslavia that share a common recent ( $20^{\text {th }}$ century) history, as well as for some other transition and emerging market economies that are experiencing structural changes in the farming sector. In addition to increasing understanding of the drivers of farm restructuring and farm size growth, the findings are also important for agricultural and rural development policy. Agricultural policy can target different farm size structures, an approach which may be important for farm competitiveness on an international basis, and changes in rural factor markets. In addition to land market and land leasing arrangements, the former can cause changes in local labour market conditions and increase local employment. The finding that an important driver of change in the farming sector may be the age of farmers/farm managers could be of crucial importance for farm labour renewal and long-term farm survival, but may be also a factor of importance in farm investment activities which can create rural jobs and increase the competitiveness of farming and the rural economy. These structural changes in farms can be supported with CAP measures for young farmers and investment subsidies, or non-CAP funds such as regional and cohesion funds.

Among the study limitations, only input-oriented UAA per farm is used as a measure of the relationship of farm land size to farm land size growth. In terms of the implications of the study comparison, this assumption should be contrasted with the use of other different input- (e.g. labour, livestock, and capital) or output-oriented farm size/farm size growth measures. The findings and implications might have been different if different farm size measures had been used. Finally, farm size growth can be also driven by other factors that were not specified in our study, such as type of farming and regional specificities, the use of different farming technologies, off-farm employment, different market structures, and production and market risks. These are issues for future research.

\section{Acknowledgements}

This study was supported with funding received from the Hungarian and Slovenian Research Agencies as a joint research project within Project N5-0094 - Impacts of agricultural policy on the regional adjustment in agriculture: A Hungarian-Slovenian comparison.

\section{References}

Adamopoulos T., Restuccia D., 2014. The size distribution of farms and international productivity differences. American Economic Review, 104(6): 1667-1697.

Adinolfi F., Capitanio F., De Rosa M., Vecchio Y., 2020. Gender differences in farm entrepreneurship: comparing farming performance of women and men in Italy. New Medit, 19(1): 69-82.

Akimowicz M., Magrini M.B., Ridier A., Bergez J.E., Requier-Desjardins D., 2013. What influences 
farm size growth? An illustration in Southwestern France. Applied Economic Perspectives and Policy, 35(2): 242-269.

Alvarez A., Arias C., 2004. Technical efficiency and farm size: A conditional analysis. Agricultural Economics, 30(3): 241-250.

Aubert M., Perrier-Cornet P., 2009. Is there a future for small farms in developed countries? Evidence from the French case. Agricultural Economics, 40(s1): 797-806.

Bakucs L.Z., Bojnec Š., Fertő I., Latruffe L., 2013. Farm size and growth in field crop and dairy farms in France, Hungary and Slovenia. Spanish Journal of Agricultural Research, 11(4): 869-881.

Bakucs L.Z., Fertö I., 2009. The growth of family farms in Hungary. Agricultural Economics, 40(s1): 789-795.

Baráth L., Fertő I., Bojnec Š., 2018. Are farms in less favoured areas less efficient? Agricultural Economics, 49(1): 3-12.

Baráth L., Fertő I., Bojnec Š., 2020. The effect of investment, LFA and agri-environmental subsidies on the components of total factor productivity: The case of Slovenian farms. Journal of Agricultural Economics. https://doi.org/10.1111/1477-9552.12374.

Barbosa N., 2020. Portuguese farming firms' growth: do human capital and managerial capabilities matter? New Medit, 19(1): 101-116.

Bartolini F., Viaggi D., 2013. The Common Agricultural Policy and the determinants of changes in EU farm size. Land Use Policy, 31: 126-135.

Beckers V., Beckers J., Vanmaercke M., Van Hecke E., Van Rompaey A., Dendoncker N., 2018. Modelling farm growth and its impact on agricultural land use: A country scale application of an agent-based model. Land, 7(3): 109.

Benke K., Tomkins B., 2017. Future food-production systems: vertical farming and controlled-environment agriculture. Sustainability: Science, Practice and Policy, 13(1): 13-26.

Bojnec Š., Fertő I., 2016. Financial constraints and farm investments in Slovenia. New Medit, 15(4): 2-9.

Bojnec Š., Fertő I., 2018. Assessing and understanding the drivers of farm income risk: evidence from Slovenia. New Medit, 17(3): 23-36.

Bojnec Š., Fertő I., 2019a. Farm household income inequality in Slovenia. Spanish Journal of Agricultural Research, 17(4): e0112.

Bojnec Š., Fertő I., 2019b. Do CAP subsidies stabilise farm income in Hungary and Slovenia? Agricultural Economics - Czech, 65(3): 103-111.

Bojnec Š., Fertö I., 2020a. Testing the validity of
Gibrat's law for Slovenian farms: cross- sectional dependence and unit root tests. Economic Research-Ekonomska Istraživanja, 33(1): 1280-1293.

Bojnec Š., Fertő I., 2020b. The growth of farms: A Hungarian-Slovenian comparison. Post- Communist Economies. DOI: 10.1080/14631377.2020.1727265.

Bojnec Š., Latruffe L., 2013. Farm size, agricultural subsidies and farm performance in Slovenia. Land Use Policy, 32: 207-217.

Chavas J.P., 2001. Structural change in agricultural production: Economics, technology and policy. In: Gardner B.L., Rausser G.C. (eds.), Handbook of Agricultural Economics, vol. 1, part 1. New York: Elsevier, pp. 263-285.

Ciliberti S., Frascarelli A., Martino G., 2020. Drivers of participation in collective arrangements in the agri-food supply chain. Evidence from Italy using a transaction costs economics perspective. Annals of Public and Cooperative Economics, 91: 387-409. https://doi.org/10.1111/apce.12263.

Colombo S., Perujo-Villanueva M., Ruz-Carmona A., 2018. Is bigger better? Evidence from olive-grove farms in Andalusia. Acta Horticulturae, 1199: 165-170.

D’Amico M., Coppola A., Chinnici G., Di Vita G., Pappalardo G., 2013. Agricultural systems in the European Union: An analysis of regional differences. New Medit, 12(4): 28-34.

De Hoyos-Ruperto M., Romaguera J.M., Carlsson B., Lyytinen K., 2013. Networking: A critical success factor for entrepreneurship. American Journal of Management, 13(2): 56-72.

Distante R., Petrella I., Santoro E., 2018. Gibrat's Law and quantile regressions: An application to firm growth. Economic Letters, 164: 5-9.

Donati C., 2016. Firm growth and liquidity constraints: evidence from the manufacturing and service sectors in Italy. Applied Economics, 48(20): 1881-1892.

Eastwood R., Lipton M., Newell A., 2010. Farm Size. In: Pingali P.L., Evenson R.E. (eds.), Handbook of Agricultural Economics. Burlington: Academic Press, vol. 4, pp. 3323-3397.

European Commission, 2013. Structure and dynamics of EU farms: changes, trends and policy relevance. DG Agriculture and Rural Development, Unit Economic Analysis of EU Agriculture. Briefs No. 9, EU Agricultural Economics.

Eurostat, 2020a. General Agricultural Census 2010. Luxembourg: Eurostat - European Statistics. Available at https://ec.europa.eu/eurostat/ (accessed 08.03.2020).

Eurostat, 2020b. Farm Structure Survey 2016. Lux- 
embourg: Eurostat - European Statistics. Available at https://ec.europa.eu/eurostat/ (accessed 08.03.2020).

Fagiolo G., Luzzi A., 2006. Do liquidity constraints matter in explaining firm size and growth? Some evidence from the Italian manufacturing industry. Industrial and Corporate Change, 15(1): 1-39.

Fertő I., Bakucs L.Z., 2009. Gibrat's Law revisited in a transition economy: The Hungarian case. Empirical Economics Letters, 8(3): 13-18.

Francesconi G.N., Wouterse F., 2015. Promoting the role of farmer-based organizations for value chain integration: the tension between program's targeting and an organization's investment strategy. Agricultural Economics, 46(4): 527-536.

Gibrat R., 1931. Les inégalités économiques. Paris: Librairie du Recueil Sirey.

Goddard J., McMillan D., Wilson J.O.S., 2006. Do firm sizes and profit rates converge? Evidence on Gibrat's Law and the persistence of profits in the long run. Applied Economics, 38(3): 267-278.

Goddard J., Wilson J., Blandon P., 2002. Panel tests of Gibrat's Law for Japanese manufacturing. International Journal of Industrial Organization, 20(4): 415-433.

Gollin D., 2019. Farm size and productivity: Lessons from recent literature (January 23, 2019). IFAD Research Series No. 34, 2018. Available at SSRN: https://ssrn.com/abstract=3321659.

Gričar S., Šugar V., Bojnec Š., 2019. Small and medium enterprises led-growth in two Adriatic countries: Granger causality approach. Economic Research-Ekonomska Istraživanja, 32(1): 2161-2179.

Guiomar N., Godinho S., Pinto-Correia T., Almeida M., Bartolini F., Bezák P., Biró M., Bjørkhaug H. et al., 2018. Typology and distribution of small farms in Europe: towards a better picture. Land Use Policy, 75: 784-798.

Huettel S., Jongeneel R., 2011. How has the EU milk quota affected patterns of herd-size change? European Review of Agricultural Economics, 38(4): 497-527.

Johnson N., Ruttan V., 1994. Why are farms so small? World Development, 22(5): 691-706.

Jones D.C., Kalmi P., 2012. Economies of scale versus participation: A co-operative dilemma? Journal of Entrepreneurial and Organizational Diversity, 1(1): 37-64.

Key N., Roberts M., 2007. Do government payments influence farm size and survival? Journal of Agricultural and Resource Economics, 32(2): 330-349.

Kostov P., Patton M., Moss J., McErlean S., 2005. Does Gibrat's Law hold amongst dairy farmers in Northern Ireland? Paper presented at the $11^{\text {th }}$ EAAE Congress, 24-27 August, Copenhagen, Denmark.

Lotti F., Santarelli E., Vivarelli M., 2003. Does Gibrat's Law hold among young, small firms? Journal of Evolutionary Economics, 13(3): 213-235.

Lowder S.K., Skoet J., Raney T., 2016. The number, size, and distribution of farms, smallholder farms, and family farms worldwide. World Development, 87: 16-29.

Lund P.J., 1983. The use of alternative measures of farm size in analysing the size and efficiency relationship. Journal of Agricultural Economics, 34(2): 187-189.

Lund P., Price R., 1998. The measurement of average farm size. Journal of Agricultural Economics, 49(1): 100-110.

Mekonnen Y., Namuduri S., Burton L., Sarwat A., Bhansali S., 2020. Review-Machine Learning Techniques in Wireless Sensor Network Based Precision Agriculture. Journal of The Electrochemical Society, 167(3): 037522.

Melhim A., O'Donoghue E., Shumway C., 2009. What does initial farm size imply about growth and diversification? Journal of Agricultural and Applied Economics, 41(1): 193-206.

Mishra A.K., Kumar A., Joshi P.K., D’Souza A., 2018. Cooperatives, contract farming, and farm size: The case of tomato producers in Nepal. Agribusiness, 34(4): 865-886.

Nikitina L., Paidi R., Furuoka F., 2019. Using bootstrapped quantile regression analysis for small sample research in applied linguistics: Some methodological considerations. PLoS ONE, 14(1): e0210668. OECD, 2009. Innovation in Firms: A Microeconomic Perspective. Paris: OECD Publishing.

OECD, 2015. The OECD Innovation Strategy: 2015 revision. Paris: OECD Publishing.

Pantazi X.E., Moshou D., Alexandridis T., Whetton R.L., Mouazen A.M., 2016. Wheat yield prediction using machine learning and advanced sensing techniques. Computers and Electronics in Agriculture, 121: 57-65.

Parker D.C., Berger T., Manson S.M. (eds.), 2002. Agent-Based Models of Land-Use and Land-Cover Change. LUCC Rep. Ser. No. 6. Bloomington: Anthropological Center for Training and Research on Global Environmental Change, Indiana University.

Piet L., Latruffe L., Le Mouel C., Desjeux Y., 2012. How do agricultural policies influence farm size inequality? The example of France. European Review of Agricultural Economics, 39(1): 5-28.

Rizov M., Mathijs E., 2003. Farm survival and growth 
in transition economies: Theory and empirical evidence from Hungary. Post-Communist Economies, 15(2): 227-242.

Rudd J.D., Roberson G.T., Classen J.J., 2017. Application of satellite, unmanned aircraft system, and ground-based sensor data for precision agriculture: A review. In: Proceedings of the 2017 ASABE Annual International Meeting. American Society of Agricultural and Biological Engineers, Spokane, WA, USA, 16-19 July.

Saiz-Rubio V., Rovira-Más F., 2020. From smart farming towards agriculture 5.0: A review on crop data management. Agronomy, 10(2): 207.

Sumner D., 2014. American farms keep growing: Size, productivity, and policy. Journal of Economic Perspectives, 28(1): 147-166.

Sumner D.A., Leiby J.D., 1987. An econometric analysis of the effects of human capital on size and growth among dairy farms. American Journal of Agricultural Economics, 69(2): 465-470.

Unay-Gailhard İ., Bojnec Š., 2019. The impact of green economy measures on rural employment: green jobs in farms. Journal of Cleaner Production, 208: 541-551.

Upton M., Haworth S., 1987. The Growth of farms. European Review of Agricultural Economics, 14(4): 351-356.

Ward A.-M., McKillop D.G., 2005. The law of proportionate effect: the growth of the UK credit union movement at national and regional level. Journal of Business Finance \& Accounting, 32(9-10): 1827-1859.

Weersink A., 2018. The growing heterogeneity in the farm sector and its implications. Canadian Journal of Agricultural Economics/Revue canadienne d'agroeconomie, 66(1): 27-41.

Weiss C.R., 1998. Size, growth, and survival in the Upper Austrian farm sector. Small Business Economics, 10(4): 305-312.

Wolfert S., Ge L., Verdouw C., Bogaardt M.-J., 2017. Big data in smart farming-a review. Agricultural Systems, 153: 69-80. 